\title{
Architecture of Residential Buildings in Bulgaria from the Revival Period
}

\author{
Regina Raycheva, University of Forestry of Sofia
}

ABSTRACT. The paper considers house architecture in Bulgarian lands during the Revival period -from the end of $18^{\text {th }}$ century to the end of $19^{\text {th }}$ century. The paper also examines the impact of climate, religion, livelihood, etc. on the development of different regional types. The resulting composition, structure, architectural image and interior, as well as adaptability to terrain conditions, adequacy to social requirements, building traditions are analyzed. Similarities, differences and local features are being considered with the intent to follow the evolution and spread of architecture, typical of the Balkan region. Comparisons are drawn between the rich city houses in Plovdiv, Koprivshtiza, Melnik, Samokov, etc., and Turkish houses in Istanbul, Edirne, Safranbolu, etc. By complying with various religious, functional, representative, climatic and terrain requirements, a distinguishable architectural language can be traced.

KEYWORDS: building tradition, residential architecture, revival architectural style, national heritage

The Bulgarian town house from the period of Late Revival has been particularly well studied and documented by a generation of researchers from the first and second half of the 20th century, with an increasing interest and appreciation, as time passed. We can say today that important Revival houses, rebuilt, reconstructed or restored, are highly valued as national heritage, as proof of the talent and artistic achievement of Bulgarian master-builders from the $19^{\text {th }}$ century.

Late Revival town houses feature symmetry as their most typical feature. In the $60 \mathrm{~s}$, authors were divided on the issue of architectural influences and origin of style. Some came to the conclusion that they were Baroque houses [1;2], others stated that Revival houses demonstrated the influence of Italian Renaissance [4]. Also, Chr. Peev [4] pointed out influences coming both by way of following examples from Istanbul, according to the desire of house-owners, or the building style developed by the master-builders, who travelled the whole Balkan peninsula (including Istanbul) in order to build for different investors. M. Bichev stated there were three different centres of architectural influence: Odessa, Vienna and Istanbul, pointing out that Vienna influence should not be underestimated at all [1]. He is of the opinion that these houses show characteristic Baroque features, like the dynamic role of the staircase in the composition, the clearly defined axes of symmetry, concave-convex elements on the facade, such as bow pediments, bow-jetties, the oval reception hall on the second floor, etc. Later, G. Kojuharov and R. Angelova stressed on the "genetic connection and firsthand role of the local architectural and building tradition in the creation and evolution of the closed symmetric house, without denouncing the presence of foreign reference and influence on the evolution and formation of its architectural image" [3]. All
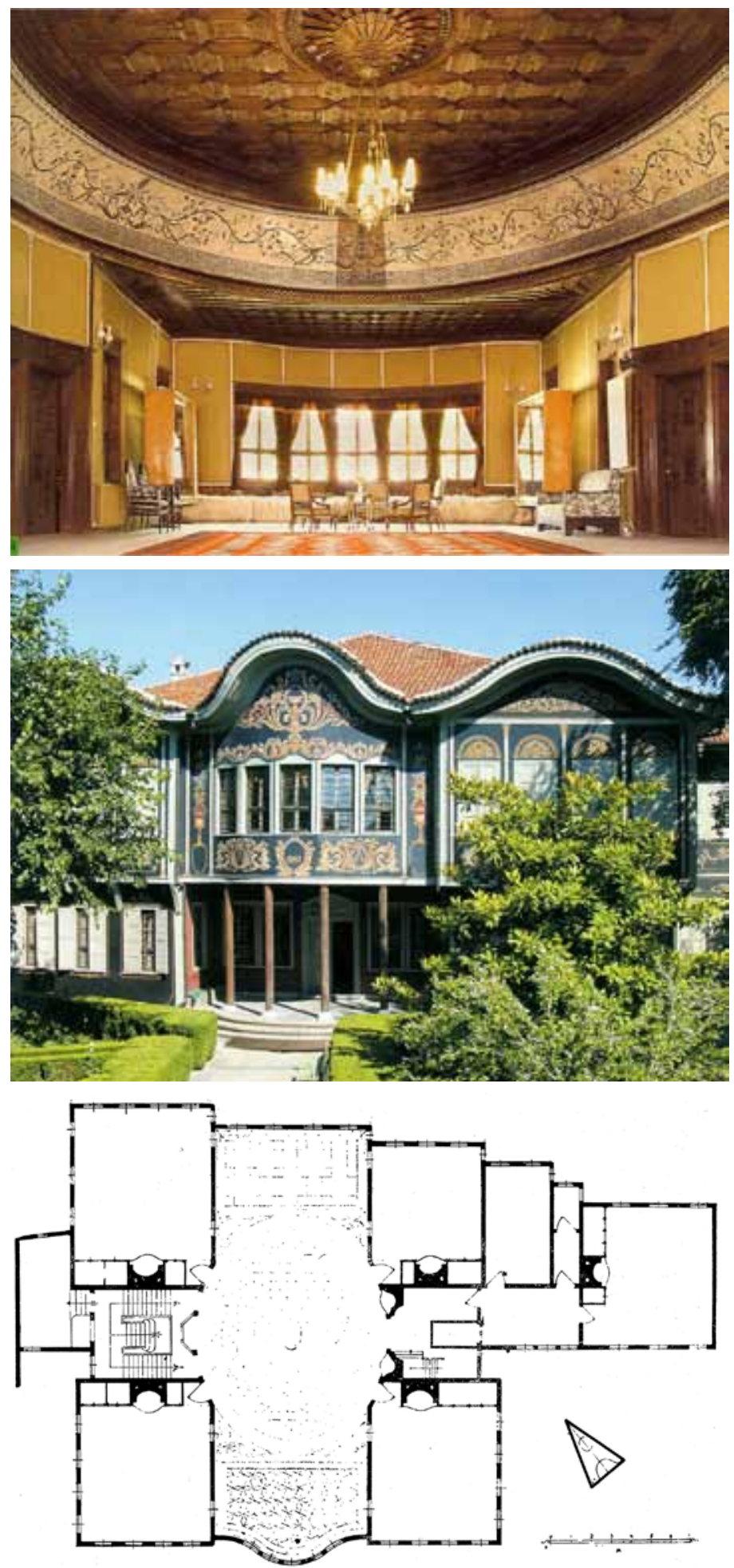

Fig. 1-3. Argir Koyumdjioglu House in Plovdiv. Hayat of the upper floor, façade [8], plan of upper floor. 

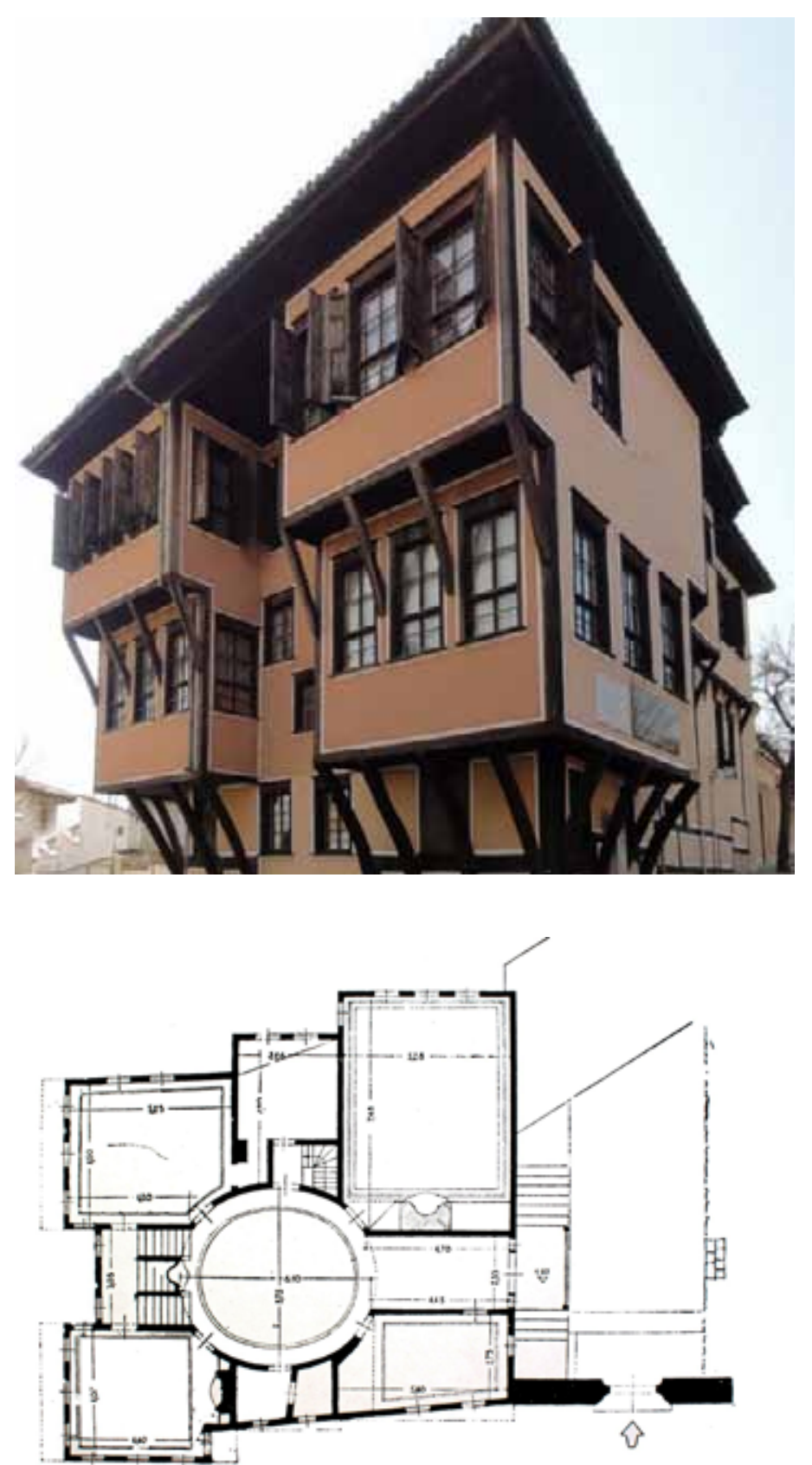

Fig. 4-5. Georgi Mavridi House (Lamartin House) in Plovdiv. Street façade [9], plan of the first floor.

authors agree on the presence of such foreign influence, but are of the opinion that the local tradition marks a long evolution, followed by these builders, creating a typical architectural language.

The purpose of this paper is to outline common features and differences between Bulgarian town houses in Plovdiv, Koprivshtitza, Samokov, Melnik and Turkish houses in Istanbul, Safranbolu, etc.

However, first of all, the basic formative factors of these buildings will be outlined.

\section{The Late Revival Bulgarian Town House}

Function. The Later Revival Town houses in Bulgarian lands were built for formal, representative functions. They differed considerably from the earlier traditional type of house, built at
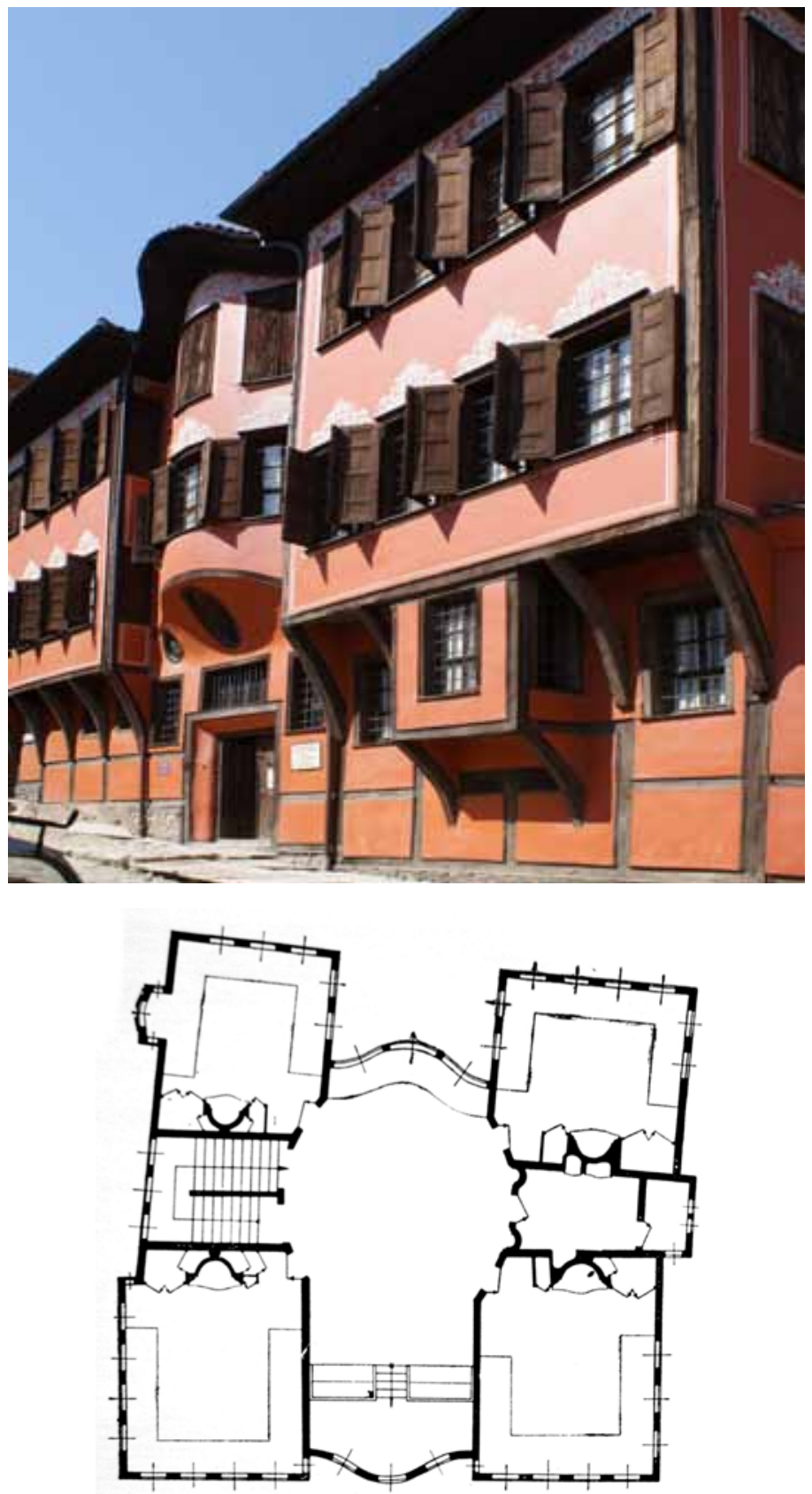

Fig. 6-7. Dimitar Georgiadi House. Street façade [8], first floor plan.

the beginning of the $19^{\text {th }}$ century, where the main activity was the processing of crops or craft production (weaving, spinning of wool etc.). The basement was used for living, while the upper storey was used for large gatherings of people on family festive occasions, such as marriage, baptising, etc. These events took place in the large vestibule on the main storey, with a place for musicians. The representative storey had a symmetrical composition, consisting of a central hall, (hayat), and usually four rooms flanked the hall on both sides; one of which was used for guests, one was a ladies' reception, other - a study of the owner, etc. Those rooms had windows looking into the hall. Such houses were owned by rich merchants or bankers in Plovdiv, Koprivshtiza, Russe, etc. Some Bulgarian architectural historians pointed out that this large hall was the closed-in balcony (chardak) in earlier village houses. 

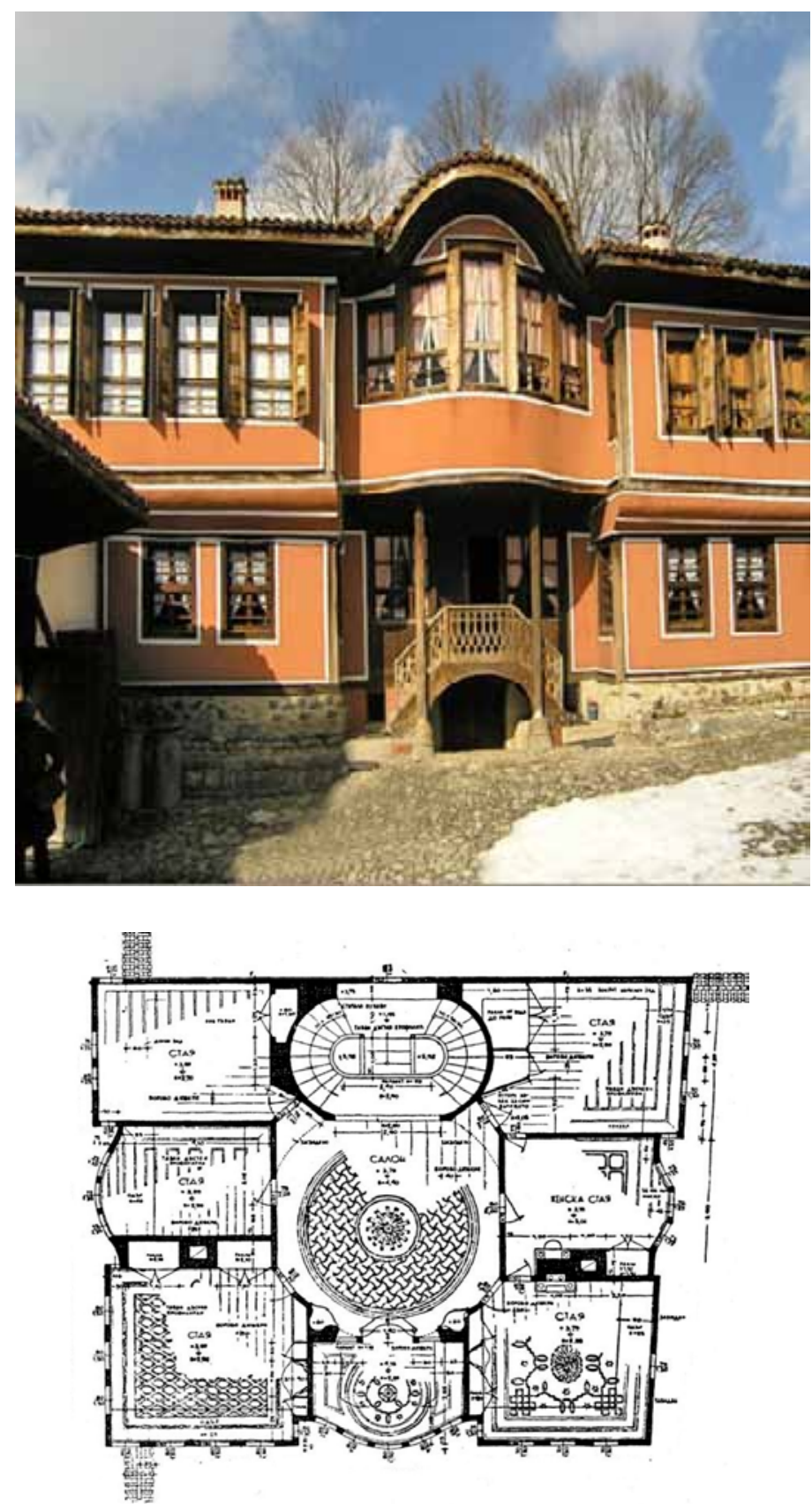

Fig. 8-9. Kableshkov House in Koprivshtiza. Yard façade, upper floor plan.

Climatic and Terrain Solutions. Considering the terrain and climate, two types of site planning solutions were possible, according to Chr. Peev [4]:

1. The house overlooked the street, when the plot bordered the street line, and had its official entrance directly from the street.

2. The house was of a freestanding type, surrounded by a garden. The main entrance gate was set in a high wall surrounding the plot; from there the visitor could enter the house by a stately entrance door under a bow-pediment portico.

Climatic conditions in Plovdiv allowed the houses to be built of the half-timber structure because of the considerably higher summer temperatures; the walls did not have to be too thick.
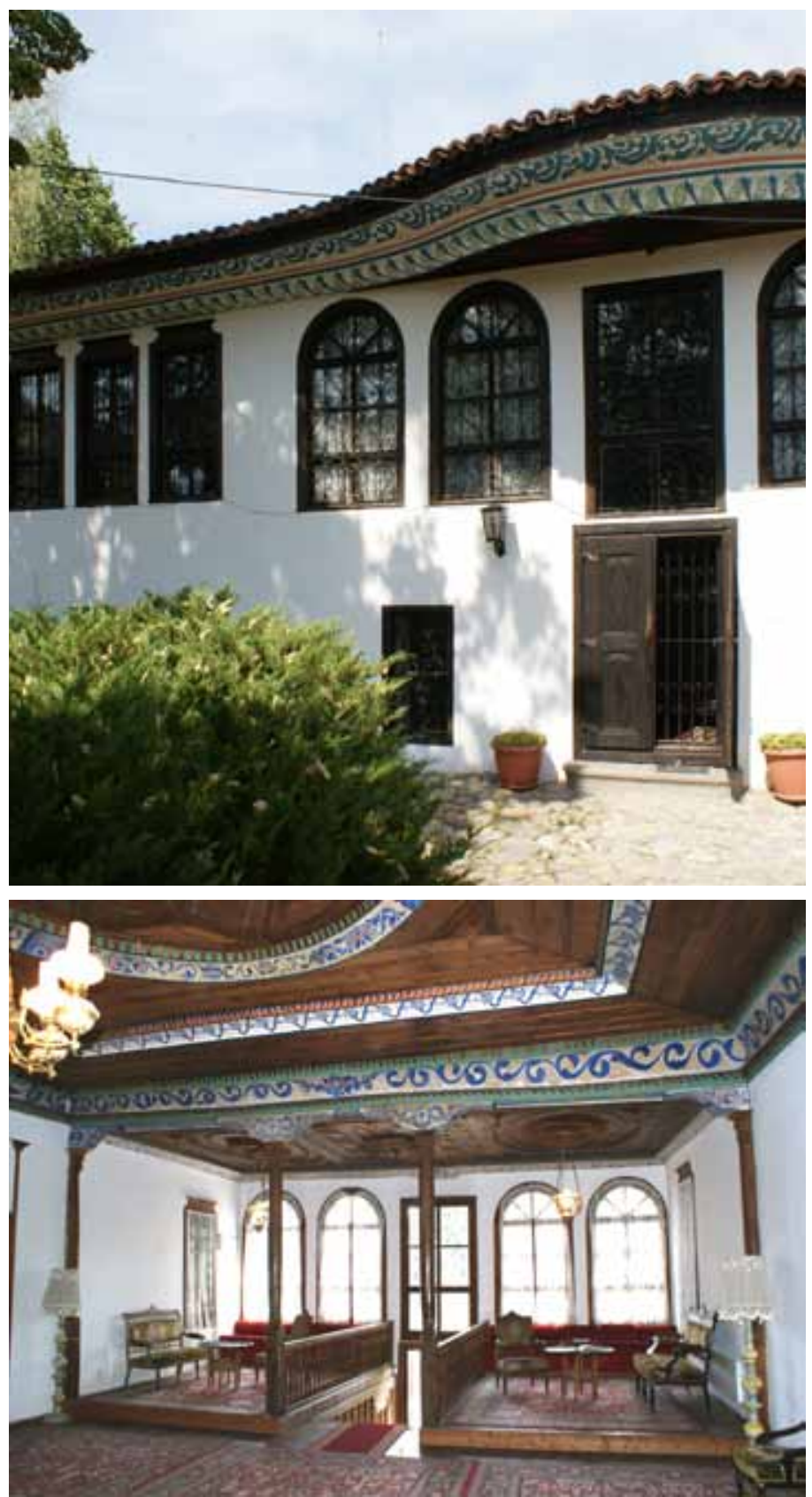

Fig. 10-11. Arie House in Samokov. Façade and interior [8].

People used the basement (which was stone-built) as basic dwelling space (also in winter); the upper floor was kept as reception space and was warmed with fireplaces accordingly.

Structure. The houses were of a mixed structure: basements were built of stone masonry, while the major storey was of the half-timber structure. The walls were built with vertical wooden structural members (posts) spaced approx. 70 to $80 \mathrm{~cm}$, forming bays filled with mud bricks or stone rubble, and the wall thus formed was plastered on both sides, with the facade decorated with beautiful wall paintings. The windows were set in slightly wider bays (1.00-1.10 $\mathrm{m}$ according to Chr. Peev [5]), grouped by two or three to form a compositional element on the facade. The house was covered by a wooden roof structure with wide overhanging eaves, covered by ceramic tiles/roof slate slabs in 

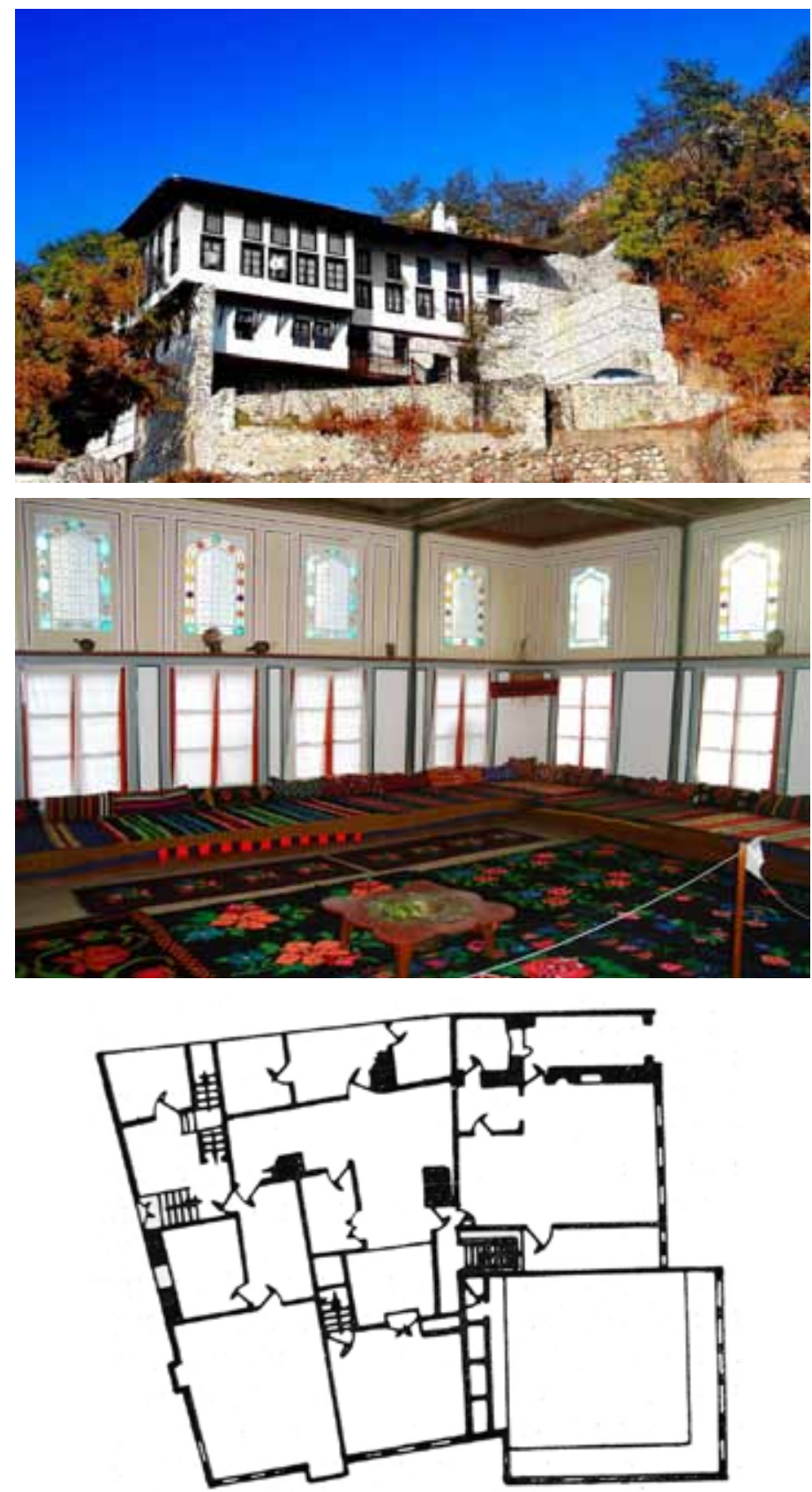

Fig. 12-14. Melnik, Kordopulu House. Façade [10], interior [11] and main floor plan.

mountain areas. The use of wooden roof structure developed rather big structural bays: Koyumdjioglu house in Plovdiv has its main storey hayat in the form of an ellipse, measuring 7 by $11 \mathrm{~m}$; The Big House of Arie in Samokov, a real palace, torn down in 1947, had a rectangular hayat, measuring 27 by $7.60 \mathrm{~m}$.

Architecture. Late Revival residential architecture can be divided into two major types: single storied houses; and two or more storied houses. The single storied type had a stone-mason basement, partly dug out in the terrain, usually used as storage area or kitchen and bath or other purposes. An entrance was reached by two symmetrical flights of steps, reaching a landing, approx. 1.0-1.50 m level above the court. Under this landing, another flight of steps lead down to a low central door of the basement. After climbing the entrance steps one entered a large

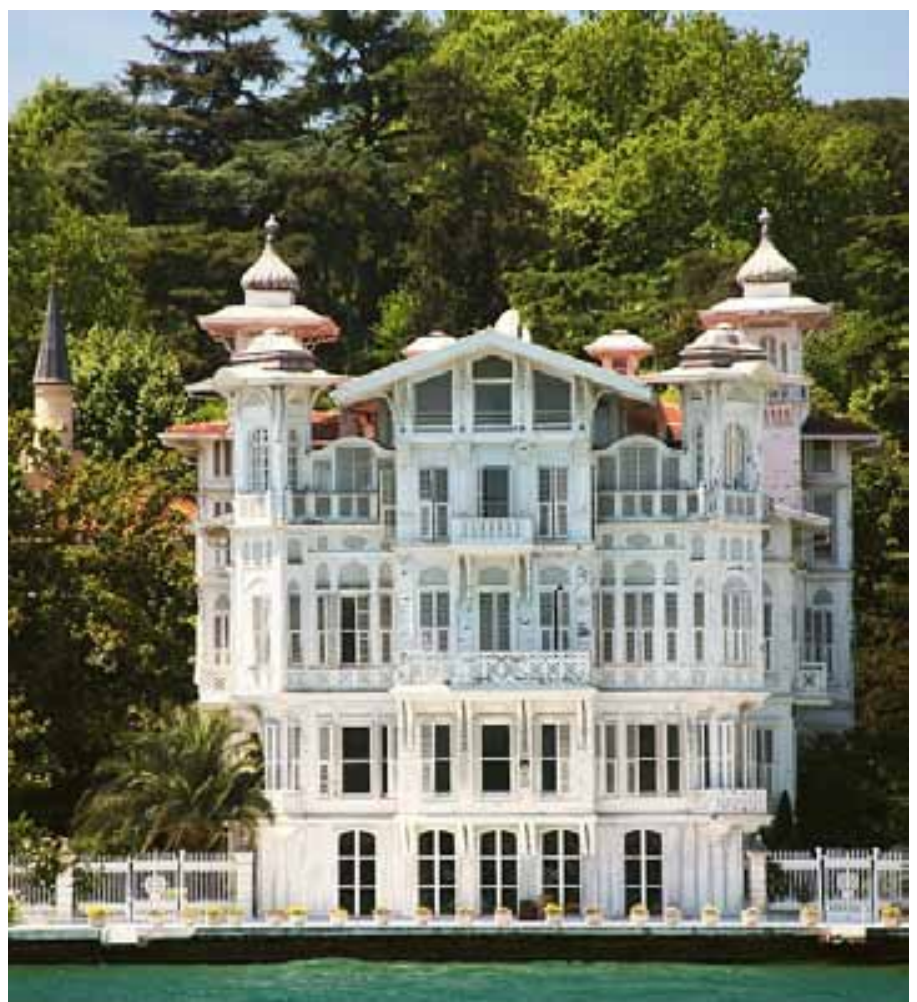

Fig. 15. Ahmet Afif Pasa Yali (Waterside mansion), Yenikoy. [12]

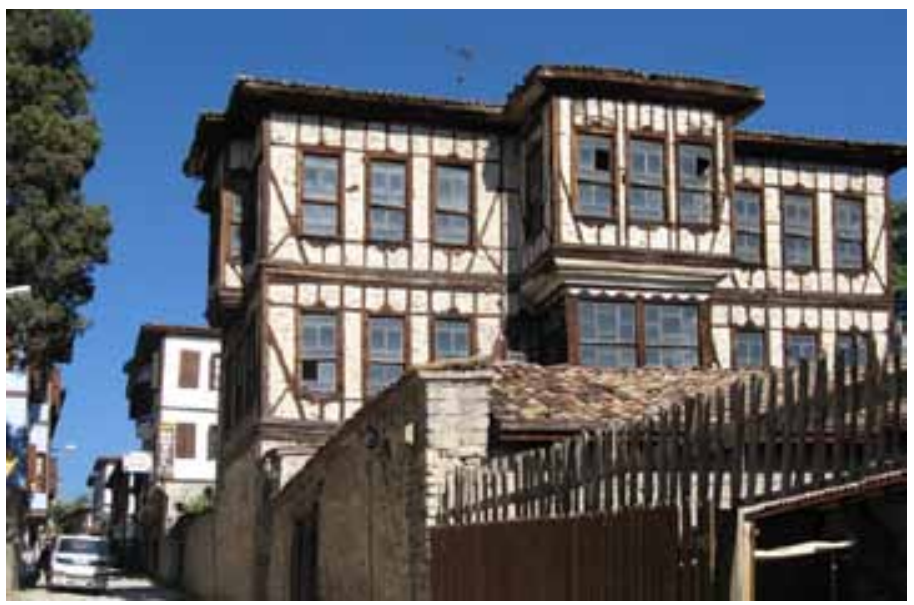

Fig. 16. Safranbolu traditional house. [13]

vestibule with a ceiling higher than the adjacent rooms. This entrance vestibule had a stately and ornamented wood carved ceiling with a central 'sun' - applied wooden rosette. This hall had a rectangular, oval/elliptic or round form. The two storied house had a considerably lower stone basement, a central hayat reached by a stately entrance under a two- or four-columned portico, recessed to form an entrance niche, leading to a large ground floor hall, thus forming a strong axis to a beautiful symmetrical stair at the bottom of the hall. This stair consisted of two flights of steps, leading up to the larger and higher hall upstairs. This one followed the rules listed above: elliptical or round form, a ceiling higher than the adjacent rooms. A wooden ceiling culminated the composition with a central rosette symbolizing the sun. The adjacent rooms were symmetrical on both sides of the hall; 


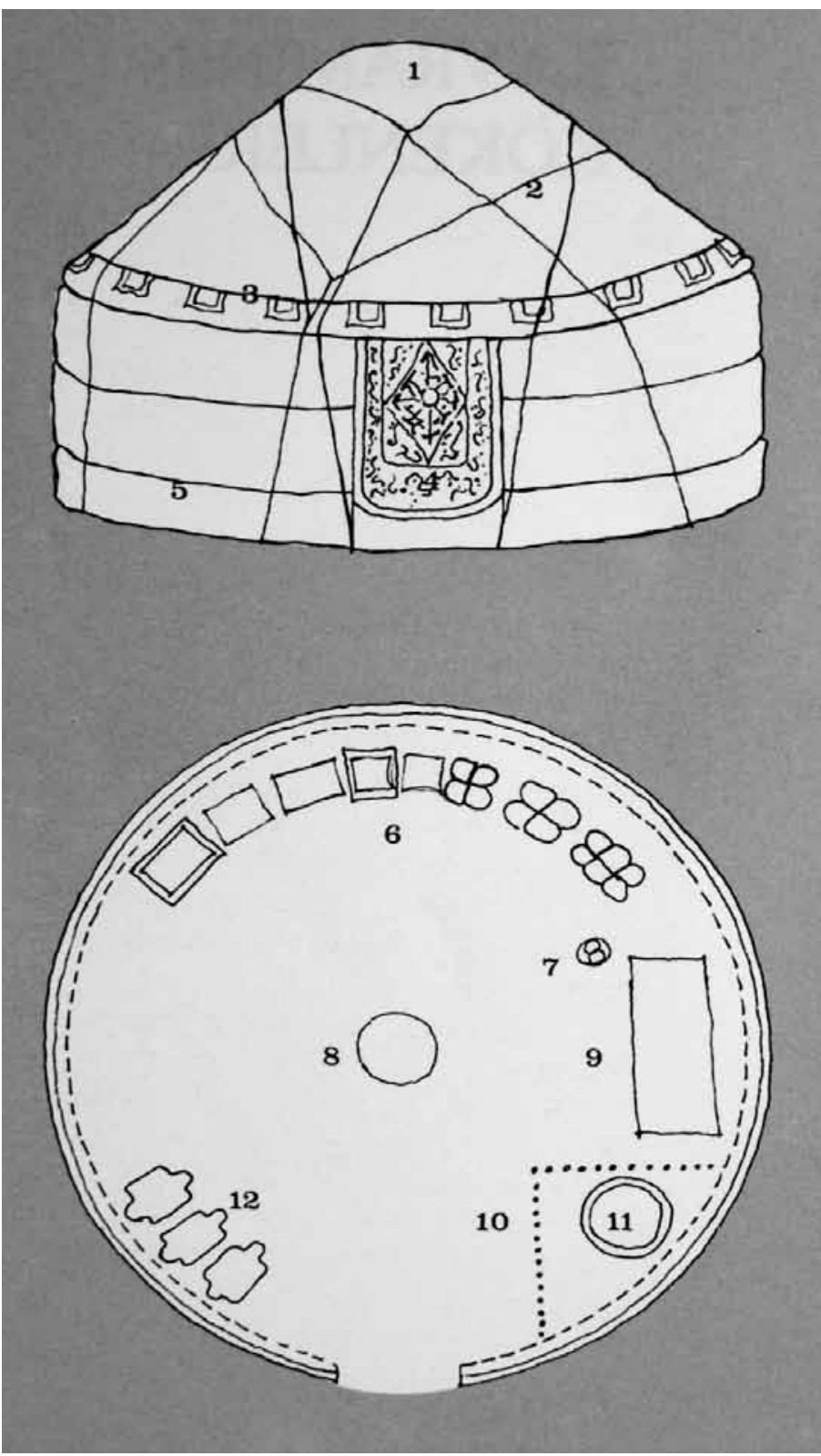

Fig. 17. The organization of space in the nomadic tent: 1 . Chimney opening; 2 . Main top cover; 3. Ridge; 4. Felt door curtain; 5 . Side cover; 6. Chest; 7. Iron stake for hanging clothes and weapons; 8 . Hearth; 9 . Raised seating platform; 10 Rush mat seating; 11. Mare's milk containers; 12. Frames for saddles and harness; 13. Threshold. Source: Kucukerman O. [7]

their doors flanked decorative niches in the concave walls of the hayat, pointing out a secondary axis, perpendicular to the major one. Bichev [1], pointed out the dynamic composition, alternating different spatial elements to culminate in this room.

Interior. Wood carving and wall-painting were the most typical decorative approaches to treat the basic surfaces of the interior: ceilings, walls, built-in storage units, fireplaces, window frames, etc. Ceilings consisted of a large decorative frame, surrounding a flat zone formed by wide planks and decorated with shaped thin wooden slats, nailed over the joints between planks. These slats usually formed a decorative pattern in the form of a net or a more elaborate star pattern. In the centre, a rosette was attached, made up of a circular arrangement of separate carved elements to form the sun. The ceiling was coved, painted with round twigs and

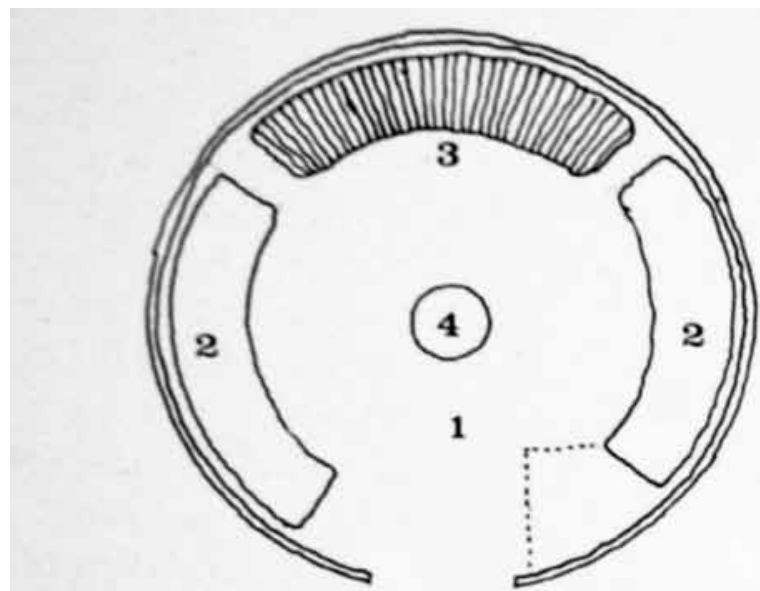

5

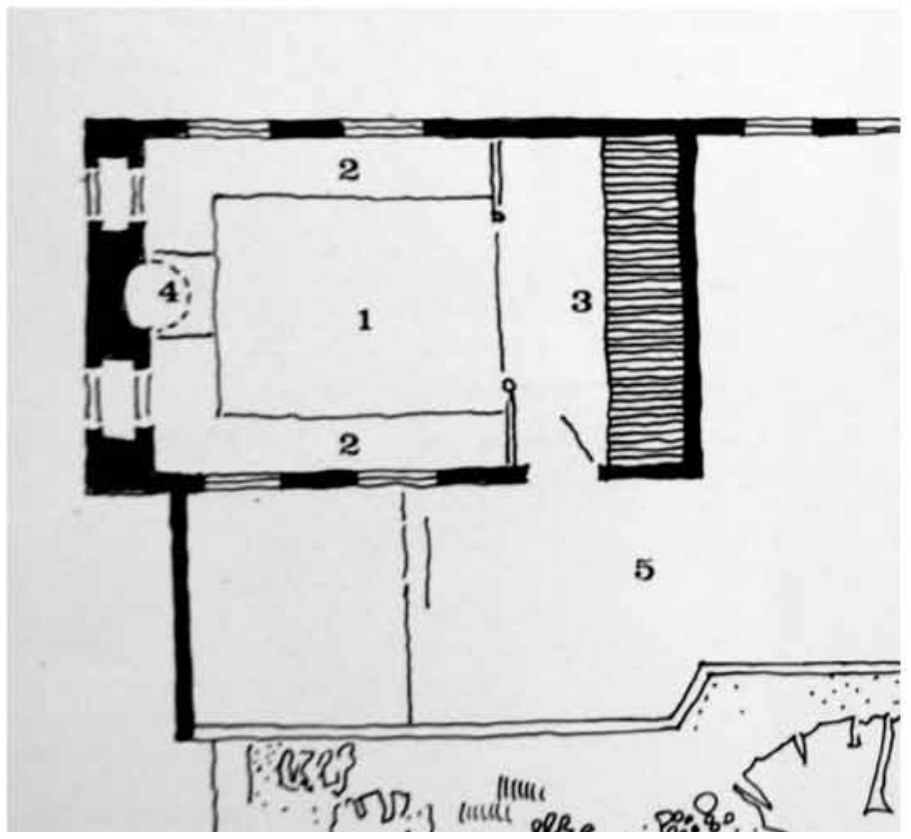

Fig. 18. Comparison of the organization of space in the tent and the house. 1. Multi-purpose central area; 2. Periphery used for seating; 3 . Closed utility areas, cupboards, chests, bedding; 4 . Heating. The central hearth in the tent is moved to a side wall in the house. Source: Kucukerman O. [7]

flowers in the Renaissance tradition. Wood carving decorated the built-in cupboards in the walls with doors richly decorated with carved panels and shaped frames. In the centre of the cupboards, a decorative arched niche was set, which was flanked by two rows of arched ventilation openings. This niche had a wooden or marble horizontal top in front; its surface was decorated with wall-paintings with architectural landscapes, flower vases, faraway exotic sea ports, palaces, gardens. Traditionally, furnishing consisted of built-in seating under the windows. The windows were set in wooden frames, crested with bow pediments; from the outside they had wooden shutters. Above the windows, a long shelf was fitted so that it covered all interior builtin units and the fireplace. On the upper storey, rooms had the cupboard-cum-niche arrangement, while heating was done with 


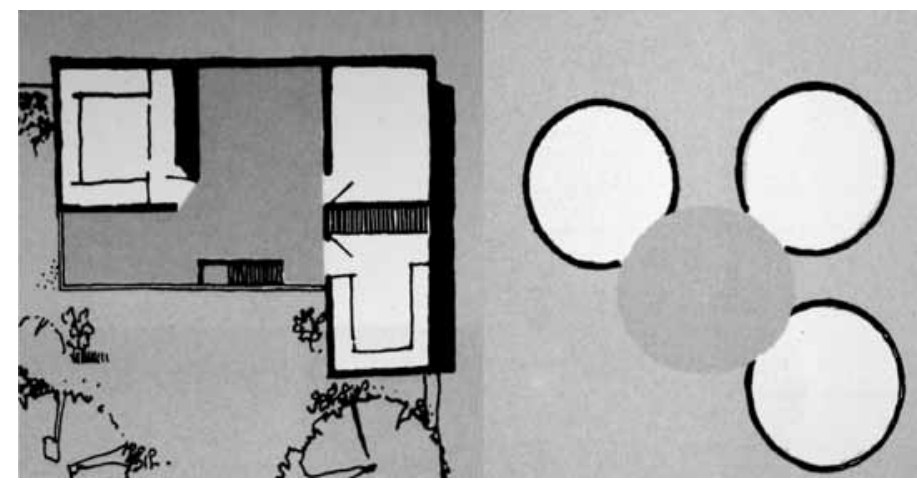

Fig. 19. Genesis of the sofa as an intermediate space between the rooms. Both the group of tents and the living units share a common area. „The relationship between the rooms and the sofa in the house is the same as that between the individual tents and their common area", Source: Kucukerman O. [7]
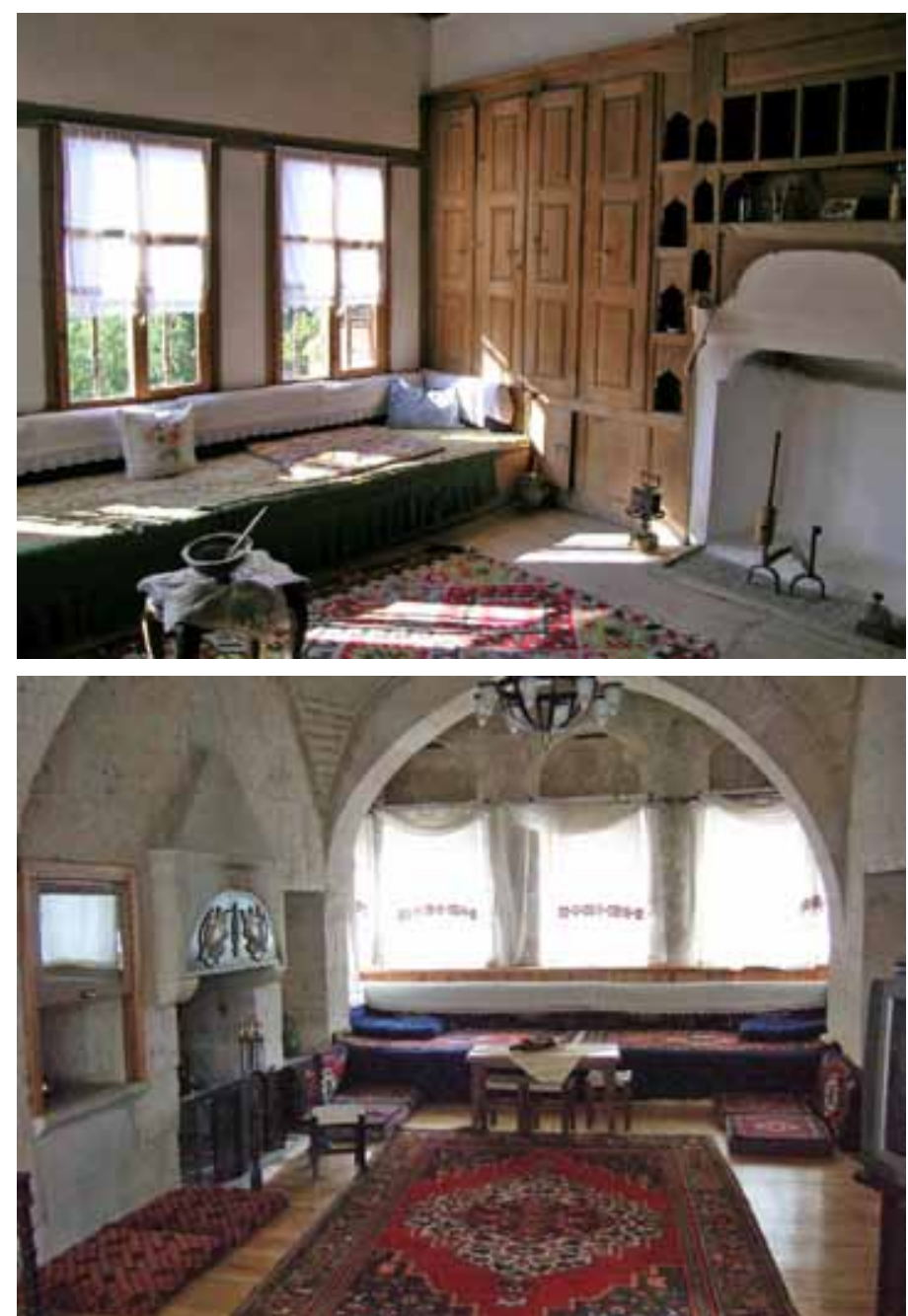

Fig. 20-21. Turkish house from Youruk Village, Safranbolu. Interior [14] and fireplace [15].

braziers; cooking was altogether removed to the living part of the house on the first storey. Walls were decorated with painted pilasters with capitals, dividing the surface into decorative panels with landscape paintings. Floors were covered with rugs. Imported furniture from Vienna or Paris formed groups according to the room function: armchairs, sofas, tables; or writing table with armchair, etc.
Examples. The Symmetrical Town House, as it is called in Bulgarian scientific publications, is well represented in Plovdiv, Koprivshtitza, Karlovo, Samokov, Russe, Melnik etc. In this publication, the examples are provided from these cities, including views, plans, interiors to show the typical architecture and furnishing.

\section{The Turkish House}

Evolution, Basic Elements and Spatial Relationships. "The traditional Turkish houses started to be built in Anatolian cities in the $15^{\text {th }}$ and $16^{\text {th }}$ centuries and spread all over the Ottoman Empire. In different regions, different types were built, depending on the climate and geographical conditions, local resources and culture" [7]. The traditional Turkish house evolved from the dwelling of the nomad tribes: the tent, or yurt. Kucukerman [6] stated that the house, as the successor to the tent, kept the same functions and the same relations between the individual tents (rooms in the house) and their common area, called a sofa. Each room was multi-functional, it provided space for sleeping, seating, cooking, eating and even bathing. In this way, the room in a Turkish house was autonomous, and the several rooms on the storey were actually a model of the family; they all shared a common sofa, which was their uniting space. The room itself had a clear three-partite division of the space. First, there was an area, which served as an entrance zone. In it, the built-in wardrobes were placed, and in the same row, the entrance door was hidden in such a way, that none from the sofa space could see inside. This area was also used by servants, who waited for orders. Next, there was a raised zone, with its periphery used for seating. This zone was made special both by the raising of level (one step high) and by means of a low parapet and columns, supporting arches. The ceiling was, therefore, developed in two parts: the entrance and the room. The fireplace was set in the larger space. All wall elements: fireplace, windows, cupboards and wardrobes, were neatly organized under one uniting element: a shelf about $2.2 \mathrm{~m}$ high from the floor; above this shelf there was only the even white surface of the wall with decorative stained windows. This second row of windows was a specific feature, giving the room definition in relation to height, and a brilliant effect of coloured light falling on the white wall opposite. Furniture was built-in seating around a central free space, which could be used either for eating or sleeping. A low round table was laid; people sat around it for meals. For sleeping, either mattresses were laid on the floor, to be taken away during the day, or the built-in seating was used. In this way, the living storey consisted of these independent rooms gathered around the central sofa space. "One of the rooms may be designated for the use of the head of the household - although its spatial interrelationships are the same as the other rooms - and is called the "Basoda", the main room" [7].

The sofa was the common space, uniting all rooms. The sofa types differed considerably from 'open' to 'closed or inner sofa', and a 'central sofa', as the last stage of the development of 19th century. These sofa types determined the type of house plan accordingly.

The central sofa featured extensions, called eyvans, between the rooms. Sometimes this extension was used to house the staircase, sometimes it was used for a seating zone. 
Structural Properties. Turkish houses had a timber structure on stone masonry basement walls that followed the street line. In order to gain space and achieve a regular rectangular shape, rooms on the living floor were widened by means of jetties, which gave a typical image of the house. Street architecture, in this way, was formed by these projecting upper storeys. The overhangs, both of jetties and the roof eaves, were thus also a result of the light timber structure. The timber skeleton allowed for better performance in earthquakes, another factor for Western Turkish regions. Timber members were infilled with adobe, mudbrick, wattle-and-daub, which did not add much weight to the building.

By comparing the Bulgarian and Turkish houses, it is possible to find many similarities and differences. Religion and family structure. Because of different religion and family life, the Bulgarian house had functional 'specialization' of the rooms, and not man-woman differentiation. The traditional rooms were ' $v$ 'kashti' (room for cooking and dining) and 'soba'(bedroom). The open balcony (chardak) was more a space for processing crops or weaving, it was also communication zone with the staircase. This functional distinction was kept in the rich merchants'houses in Plovdiv and Koprivshtitza. Rooms were accessible by a door that was usually diagonally placed in the plan of the room. The Turkish house was one of a Muslim extended family; because of polygamy, it consisted of many nuclear families. Therefore its structure of independent living units allowed for their division and privacy. The spaces for women and men were thus easily divided into 'selyamlik' and 'haremlik'. The interior of the rooms could not be seen from the hall. The hall was the main gathering and production space in the house.

Plan. Turkish houses had a clear four-partite plan of the living floor, with a large cross-shaped central hall with eyvans, which served as a distributing space between the four rooms. This space had no analogue in Late Revival houses in Plovdiv; however, the large hall might be seen as an organizing space of similar functions. Visually, the four eyvans divided the hayat, while in Plovdiv houses the hall was a unifying feature.

The interiors of Turkish and Bulgarian houses differ considerably, although individual elements exist in both types. The division of 'service area and central area' in the room space does not exist in Bulgarian houses. Built-in furniture, though, is present in both types. The basic difference, in the author's opinion, is the height of the main living storey. Due to restrictive building regulations for non-Muslims, the height was kept to 3.00 $\mathrm{m}$ versus $3.60 \mathrm{~m}$ for Muslim population. Climatic reasons have brought about a higher room space, obviously to draw the hot air above and keep the cool in summer. The second row of windows is very rare: from the examples given, only Kordopulu house in Melnik (Figure 16) has a double row of windows. Increased height brought about a different silhouette and a different proportion in facade structure: houses in Istanbul, Safranbolu, etc., are much higher. Bulgarian house architecture produces in general a typical horisontal facade, featuring wide roof eaves and the supporting brackets under the jetties. Examples of one-storey houses in Koprivshtitza, Samokov (Figure 13), are often present.

Facade treatment. Wall-painting as exterior decoration was not common in Turkish houses; however, the inside walls were often painted with floral motifs. On the contrary, Bulgarian builders

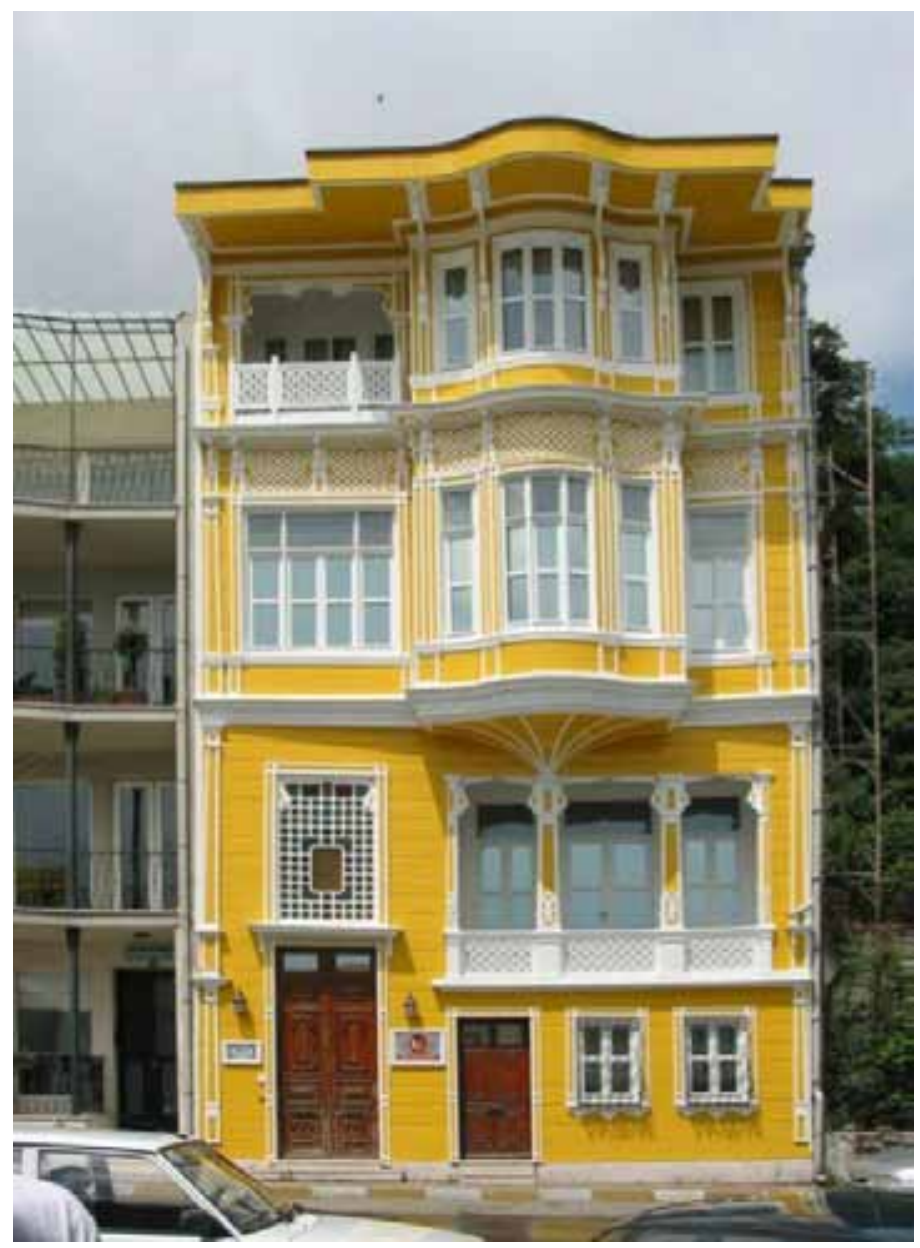

Fig. 22. Istanbul houses feature considerable height and ecclectic facade decoration. [16]

had turned to it as a characteristic device, both from the outside and the inside. Wood-carving was widely used for decoration in both types. Bulgarian façades featured porticos on wood columns, over entrances, especially in the case of freestanding houses in a garden environment. Pediments marked a difference: bow pediments, convex-concave 3D forms, were typical in Plovdiv, Koprivshtiza etc. Turkish houses in Safranbolu had triangular pediments; the houses in Istanbul showed Baroque motives and sometimes bow pediments. The preference for 'star' motives and geometrical patterns on the ceiling was Turkish, whereas Bulgarian builders preferred 'sun'motives with plant ornaments, round patterns, flowers, undulating rays etc. Fireplaces usually had the same conical awning shape, although shorter than the ones in the Turkish houses; but in certain regions they were placed in the corner of the room and had a straight form. Decorative niches were present in both types as part of built-in storage furniture, decorative flower vase motifs were depicted in wall paintings. After comparison, it is possible to conclude that the style developed during the second half of 19th century was a continuation of local building tradition, with a number of references from other Oriental and West European sources, ecclectically grouped in the manner of mix of styles in the late 19th century. Thus, an architectural vernacular language was formed, using similar 'words', to tell a different story. 


\section{REFERENCES}

1. Бичев, М. Български барок. София: Наука и изкуство, 1955. Стр. 78-82.

2. Златев, Т. Българската къщза през епохата на Възраждането. София: Наука и изкуство, 1955. Стр. 25-26.

3. Кожухаров, Г., Ангелова, Р. Пловдивската симетрична къща, София: БАН, 1971. Стр. 165-166.

4. Пеев, Хр. Пловдивската къща през епохата на Възраждането, София: Техника, 1960. Стр. 77.

5. Пеев, Хр. Студии върху българската възрожденска архитектура, София: Наука и изкуство, 1956. Стр. 17, 62-76.

6. Kucukerman, O. Turkish House: In Search of its Spatial Identity. Istanbul: TTOK, 1991. P. 66.

7. Polvan, S., Raycheva, R. Comparative Analysis Of $19^{\text {th }}$ C Dwelling Architecture in Turkey and Bulgaria. Fourth Conference „Innovations in Woodworking Industry and Engineering Design”. Sofia, 2012, Vol. I, № 1, p. 63-70.

8. Photos № 1, 6, 10, 12 by Regina Raycheva.

9. 48745631 [online]. Panoramio [cited 22.06.2012]. http://www.panoramio. com/photo/48745631

10. index.php?lang=BG\&menu=gallery [online]. Kordopulova-house com [cited 16.09.2011]. http://www.kordopulova-house.com/index. php?lang=BG\&menu=gallery

11. House of Kordopoulos Melnik 2.jpg [online]. Wikipedia [cited 01.07.2012.]. http://en.wikipedia.org/wiki/File:House_of_Kordopoulos_Melnik_2.JPG

12. showthread.php?t=999651 [online]. Skyscrapercity [cited 09.05.2012]. http://www.skyscrapercity.com/showthread.php?t=999651

13. Safranbolu [online]. Webshots [cited 08.05.2012). http://good-times. webshots.com/photo/2015340970015376128msrzkd

14. Interior View of Old Turkish House, Yoruk Village, Safranbolu [online]. Webshots [cited 09.05.2012]. http://travel.webshots.com/ photo/2382993840011713375hAwPNZ

15. Traditional Safranbolu Housing [online]. Webshots [cited 09.05.2012) times.webshots.com/photo/2618166010055513482OUKscP

16. Istanbul - House at the Bosphorous in Sariyer [online]. Webshots [cited 09.05.2012]. http://travel.webshots.com/ photo/1202138329036172436amqJEI

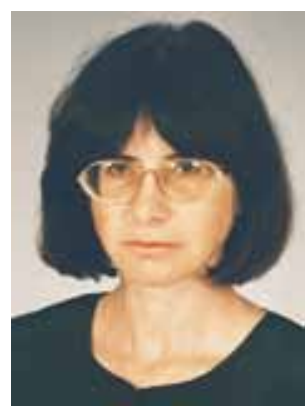

Regina Raycheva, (Sofia, 1956). graduated architecture at the University of Architecture, Construction, and Geodesy (UACG) in Sofia in $1980, \mathrm{PhD}$ in architecture from UACG in 1996, Associate Professor in 1999. Major field of study: interior architecture, design, history of furniture. Presently works as Associate Professor at the University of Forestry in Sofia, Bulgaria; teaches "Styles in interior and furniture”, „Interior Architecture", and is tutor to diploma students and Doctoral students. Elected Head of Department "Interior and Furniture Design" at the Faculty of Forest Industry for the period 2004-2007. Previously worked as Furniture Designer and Interior Architect in Sofia, and after that, as an Assistant and Lecturer at The University of Forestry in Sofia, Lecturer at Higher Construction School „Luben Karavelov”, teaching Interior to students in architecture.

Publications include articles in journals, participations in Scientific Conferences in Bulgaria and abroad. Major fields of research: Interior Design, History of Interior and Furniture, History of Architecture, Furniture Design, Design Education. Major publications include the following three study books: Interior Architecture, History of Interior and Furniture; Styles in Interior and Furniture:

- Райчева, Р. Вътрешна архитектура, София, Лесотехнически университет, 1996.

- Райчева, Р. История на интериора и мебелите, София, Мартилен, 1999.

- Райчева, Р. Стилове в интериора и мебелите, София, Мартилен, 2012. Membership: Union of Bulgarian Architects.

Regina Raycheva speaks excellent English, good French and German. Coordinator of project TEMPUS S_JEP-12479-97, later Institutional Coordinator of the UF under Socrates and now Erasmus Program of the University of Forestry. Organizer and coordinator for an Intensive Program in 2005 (Erasmus 76946-IC-1-20041-BG-ERASMUS-IPUC-1) with students and teachers from 6 universities from abroad taking part, also participating as lecturer and teacher in Intensive Programs at Salzburg University of Applied Sciences.

\section{Contact Data}

Regina Raycheva, Assoc. Prof., arch., PhD

University of Forestry, Dept. of Interior and Furniture Design

10, Kliment Ochridski Blvd., 1756 Sofia, Bulgaria

Phone/fax: +35929624198

Mobile phone: +359899864347

E-mail: rexi@abv.bg 